\title{
A poética do encontro em Estação das chuvas, de José Eduardo Agualusa
}

\section{The poetics of the encounter in Rainy season, by José Eduardo Agualusa}

\author{
Adriano Guedes Carneiro*
}

\begin{abstract}
RESUMO: Estação das chuvas (2010) narra a estória de Lídia do Carmo Ferreira e do narradorjornalista. Engloba um período da história de Angola, a partir da Independência, abrangendo acontecimentos anteriores e posteriores. Há uma perspectiva crítica, via "metaficção historiográfica”, no universo pós-moderno, em que a história oficial é permanentemente questionada. Há o estreitamento dos limites entre a história e a ficção, como no episódio da televisão da cadeia de São Paulo. O autor estabelece a construção de uma poética do encontro, através do convívio e da comunicação consensual entre os personagens, representantes de vários matizes políticos, ideológicos e étnicos, com o fim de oferecer a possibilidade de uma Angola diferente daquela que foi determinada pela conduta do MPLA e de Agostinho Neto.
\end{abstract}

PALAVRAS-CHAVE: Estação das chuvas; José Eduardo Agualusa; Angola; poética do encontro.

ABSTRACT: Rainy season (2010) tells the story of Lídia do Carmo Ferreira and the narratorjournalist. It covers a period of the history of Angola, starting from Independence, covering previous and subsequent events. There is a critical perspective, via "historiographical metafiction", in the postmodern universe, in which official history is permanently questioned. There is a narrowing of the boundaries between history and fiction, as in the television episode of the São Paulo's prison. The author establishes the construction of a poetics of the encounter, through conviviality and consensual communication between the characters, representatives of various political, ideological and ethnic nuances, in order to offer the possibility of an Angola different from that determined by the conduct of the MPLA and Agostinho Neto.

KEYWORDS: Rainy season; José Eduardo Agualusa; Angola; poetic of the encounter.

\footnotetext{
* Mestrando do Programa de Pós-Graduação em Estudos Literários da Universidade Federal Fluminense, bolsista CAPES. E-mail: adrianoguedes.carneiro@hotmail.com. ORCID: https://orcid.org/o000-0002-5830-5128.
} 


\section{Introdução}

Várias leituras são possíveis para o romance de José Eduardo Agualusa, Estação das chuvas. Aqui, propomos uma leitura a partir da perspectiva da poética do encontro. Poética com o sentido que advém do verbo grego poiesis

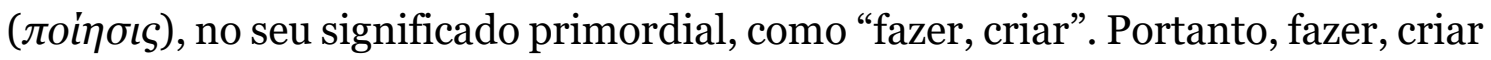
o encontro.

Pretende-se demonstrar, com o presente artigo, como o autor realizou um verdadeiro encontro entre os vários atores sociais responsáveis pela construção da Angola contemporânea, os quais estão representados, no texto, pelos diversos personagens que o compõem.

Estes atores sociais, no mundo real, realizaram encontros uns com os outros apenas em meio ao campo de batalha, na arena de guerra, através dos conflitos, que somente eram resolvidos pelas balas, sob o custo do sangue, de vidas humanas, ao longo de mais de vinte e sete anos de guerra civil e de uma "ditadura" de mais de quarenta e cinco anos, totalizando perto de setenta anos de conflitos civis e militares, armados e não armados, sem contar ainda todo o tempo de dominação colonial. No texto, contudo, estes atores sociais representados pelos personagens conseguem conviver consensualmente e compartilhar, sem se matarem uns aos outros, uma realidade possível.

O escritor nascido no Huambo se utiliza de vários recursos para atingir os seus objetivos. E um destes é o uso de técnicas narrativas típicas do pósmodernismo, que já tem se tornado uma marca da sua escrita. Tanto que alguns críticos ainda consideram a impossibilidade de classificar a obra de Agualusa ou de inscrevê-la no cânone africano, justamente porque não admitem a pósmodernidade em África ${ }^{1}$.

Linda Hutcheon (1991), por exemplo, também não concebia o pósmodernismo como uma ocorrência factível de ser encontrada no continente africano, pois, como manifestação típica de um capitalismo tardio (no sentido de muito desenvolvido, mas que já vai tarde), conforme preconiza o crítico marxista Fredric Jameson (1989), não podia subsistir em regiões em que a economia era 
muito atrasada e frágil, como era o caso da africana, que apenas tinha se visto livre do jugo colonial há poucas décadas. Ao contrário, o pós-modernismo deveria provir de países capitalistas desenvolvidos e complexos, como é o caso dos EUA ou dos países europeus. Todavia, se pensarmos na globalização, mais do que a econômica, a cultural, quando há a exposição de regiões e pessoas a todo tipo de valores culturais e sociais, talvez possamos justificar e admitir a existência de uma arte pós-moderna em solo africano, elaborada por africanos. E a economia angolana, principalmente após 1992, foi exposta à abertura do mercado, ao chamado neoliberalismo e a toda sorte de mecanismos desenvolvidos capitalistas, principalmente após a descoberta de petróleo no seu território.

Além disso, José Eduardo Agualusa é um homem que viaja pelo mundo e residiu durante anos na Europa, em vários países, como Portugal, Alemanha e Irlanda. Teve residência também no Brasil, em Recife e no Rio de Janeiro. Como jornalista e escritor, tem travado conhecimento com as mais variadas tendências artísticas mundiais. Por mais que seja angolano, sua visão de mundo será pautada pela sua experiência, pelo que aprendeu também em suas viagens internacionais e pelo contato que manteve com diversas culturas.

No artigo, ainda procuraremos elencar outras características literárias e culturais presentes em Estação das chuvas que contribuam para a construção e a formação da ideia do encontro. Entre estas é possível destacar a própria personagem Lídia do Carmo Ferreira, que pode ser entendida como metonímia de Angola, mais especificamente da República Popular de Angola. Na origem de ambas, da personagem e do país, está presente uma violência: o antepassado madeirense de Lídia que estuprava as mulheres da casa, conforme lemos nas páginas de Agualusa, e a Guerra de Independência, travada a partir de 1961 contra a metrópole colonial portuguesa. Poderíamos regredir ainda mais no tempo e buscar a origem de Angola em outra violência: a famigerada Conferência de Berlim (1885), na qual as potências europeias, como verdadeiros bucaneiros dividindo o butim, repartiram a África entre si, sem qualquer consideração com os povos, tribos, etnias e costumes dos habitantes originais dos territórios desmembrados. Lídia, como a República Popular, desaparece em 1992.

Da mesma forma, é preciso que tenhamos um outro olhar sobre a história de Angola em si, para além daquilo que é narrado pelo MPLA (Movimento 
Popular pela Libertação de Angola) em seus quase quarenta e cinco anos de poder. A escrita de Agualusa é uma denúncia perpétua dos crimes cometidos por esse partido político em todo esse tempo, como, por exemplo, aqueles cometidos no dia 25 de maio de 1977, com a repressão à revolta de Nito Alves, cuja apuração a história ainda aguarda, pois milhares de pessoas foram condenadas à morte, sob a acusação de que atentavam contra a revolução.

A imagem de Angola no início, quando da retomada da guerra civil, e também ao final do livro é o retrato de um país morto: "Este país morreu!" (AGUALUSA, 2010, p. 217) é a última coisa que se diz no romance. Um país soterrado pelas cinzas. Sim, um país coberto de cinzas, mas, como fênix, também passível de renascimento.

\section{Preparando o encontro}

\subsection{Sobre o título}

Angola, ao longo do ano, possui duas estações climáticas bem definidas: a época seca e fria, o chamado "cacimbo", de maio até agosto, e a época chuvosa e quente, de setembro até abril. Tanto a Independência, proclamada em 11 de novembro de 1975, quanto a eclosão da guerra civil em 1992 deram-se na estação das chuvas.

Chuva tem uma simbologia ambígua, pois tanto pode representar a esperança, o refrigério, pois ela é necessária para a lavoura, por exemplo, para que haja sucesso na colheita, quanto pode vir a representar a dor, a lágrima, o sofrimento; daí pensar na "Comissão das Lágrimas", o famigerado grupo que teria sido criado para avaliar e decidir quem mais deveria morrer na época dos fracionistas (a Revolta de Nito Alves, de 25 de maio de 1977). Também faz pensar na guerra, que dizimou milhares de angolanos desde a época colonial. A intenção do autor parece-nos ser justamente esta, que é deixar-nos na encruzilhada, num lugar entre a esperança e a dor. 
Além disso, é possível estabelecer uma relação com o poema "Aqui no cárcere”, de Agostinho Neto,

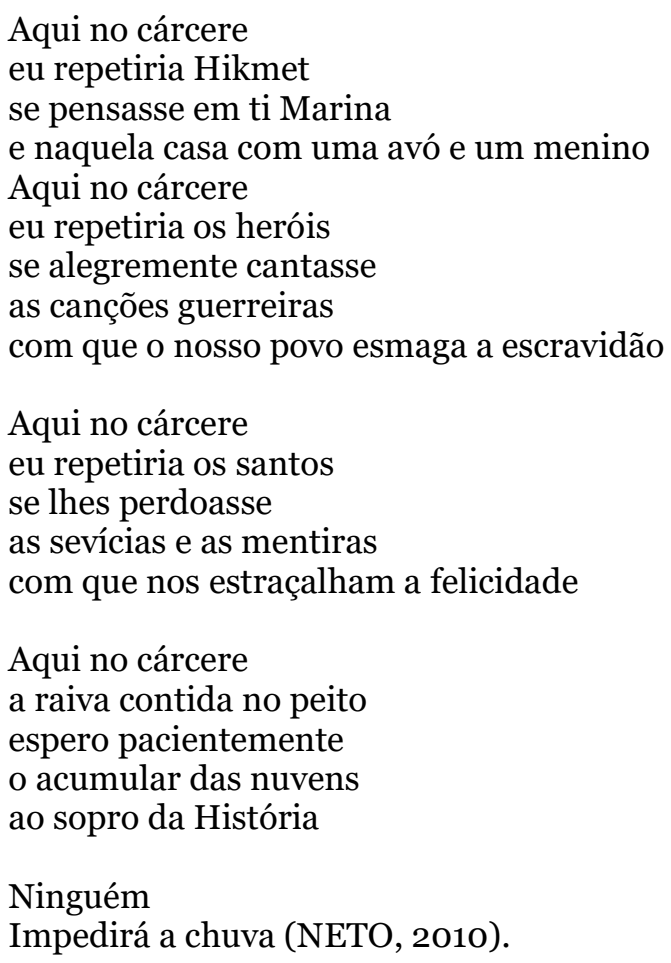

justamente por causa dos seus últimos versos: "Ninguém/ impedirá a chuva”. A chuva, no poema de Neto, como representação da realização do sonho de independência. No livro de Agualusa, a estação das chuvas poderia representar uma nova - ou efetiva - libertação de Angola. Porém, agora, libertando-se da história oficial e das garras do MPLA, representado univocamente pelo autor do poema e, durante muitos anos, presidente, Agostinho Neto.

\subsection{Decifrando os paratextos editoriais}

Estação das chuvas deixa dúvidas sobre qual é o pacto a ser celebrado entre o autor e o leitor. A narrativa deve ser encarada como história ou ficção? Através dos paratextos, podemos ir perscrutando o texto para decifrar as verdadeiras intenções do autor. 
O livro é dedicado a Mário Pinto de Andrade (AGUALUSA, 2010, p. 7), que é personagem, mas também foi um importante intelectual e ativista político, inclusive um dos fundadores do MPLA. Foi também um dissidente político, pois foi o responsável pela chamada "Revolta Activa", que levou ao rompimento com o grupo de Agostinho Neto, fato este que também é abordado no texto.

Nos agradecimentos, encontramos a informação (ou desinformação) de que: "Este livro deve muito a alguns amigos, que me apoiaram durante o trabalho de pesquisa e documentação, ou se dispuseram a partilhar comigo as suas memórias" (AGUALUSA, 2010, p. 9). O autor, propositadamente, mistura a realidade e a ficção, aludindo à sua pesquisa, à documentação e às pessoas reais que partilharam “as suas memórias”. História ou ficção, a dúvida persiste!

Na contracapa da primeira edição do livro, em 1996, pelas Publicações Dom Quixote, de Lisboa, Portugal, havia a indicação de que se tratava de uma "Biografia romanceada de Lídia do Carmo Ferreira" (SILVA, 2013, p. 116-117). Fato este que levou alguns leitores a afirmarem que tinham realmente conhecido a personagem, em tempos passados. Contudo, na edição brasileira da Editora Língua Geral, de 2010, está escrito: "Neste livro de José Eduardo Agualusa, os limites entre a ficção e a história são dissolvidos por meio de uma técnica sofisticada, de hábil enxadrista do gênero romanesco [...]" (AGUALUSA, 2010, p. 222). Aqui, fica bastante claro e explícito que estamos defronte a um romance. $O$ autor está estabelecendo com o leitor o pacto romanesco. Não é realidade, mas ficção. É um universo ficcional. Finalmente, a dúvida é desfeita de uma vez por todas.

\subsection{O texto pós-modernista}

Estação das chuvas é um romance pós-moderno. No livro, encontramos diversas características que nos permitem realizar essa classificação. E como tal, ele é considerado uma "metaficção historiográfica”, pois:

[...] sua autoconsciência teórica sobre a história e a ficção como criações humanas passa a ser a base para seu repensar e sua elaboração das formas dos conteúdos do passado. [...] é outra característica da natureza 
contraditória inerente à metaficção historiográfica, pois ela sempre atua dentro das convenções a fim de subvertê-las. Ela não é apenas metaficcional; nem é apenas mais uma versão do romance histórico ou do romance não-ficcional (HUTCHEON, 1991, p. 22).

Longe de fazer como os antigos romances históricos, que procuram se adequar a uma narrativa mais ou menos oficial sobre os fatos e acontecimentos descritos, na metaficção historiográfica há o questionamento de toda a história e de todas as suas versões, procurando abrir espaço para outras indagações e interpretações ainda desconhecidas. Abrem-se fendas no edifício histórico. Procuram-se por outros caminhos por onde andar e refletir o nosso conhecimento.

O tom geral do romance é de ironia, de galhofa, pois "é sempre uma reelaboração crítica, nunca um 'retorno' nostálgico” (HUTCHEON, 1991, p. 21). O retorno ao passado se dá de uma forma irônica, questionando, rindo, pondo em dúvida a versão oficial sobre os acontecimentos narrados.

O romance é marcado pela fragmentação. Talvez porque o autor pósmoderno não siga nenhuma narrativa-mestra ou metanarrativa que lhe explique a totalidade das coisas. Ou como sugere Appiah, de forma irônica, dizendo que o pós-modernismo "é uma metanarrativa do fim das metanarrativas" (APPIAH, 1997, p. 197). Isso se traduz no texto: lapsos temporais, multiplicidade de narradores, incertezas sobre os acontecimentos e fatos, parcialidade, hibridismos de gêneros literários.

"É assim, pelo menos, que imagino a cena (eu não estava lá)" (AGUALUSA, 2010, p. 17). O narrador-jornalista nos apresenta a cena da proclamação da Independência de Angola para nos dizer mais à frente que é apenas a sua imaginação, pois ele não estava presente. Então como podemos ter certeza de que os fatos narrados efetivamente aconteceram? O narrador de Agualusa nos conta a versão oficial justamente para colocá-la em dúvida, para levar a cena ao descrédito. Se não temos certeza de como efetivamente se realizou a independência do país - momento de grau máximo de importância na história recente angolana - não podemos ter certeza de mais nada. "Na ficção os narradores passam a ser perturbadoramente múltiplos e difíceis de localizar ou deliberadamente provisórios e limitados” (HUTCHEON, 1991, p. 29). 
Há também aqui todo um questionamento sobre a noção de consenso, até então estabelecida e internalizada no humanismo:

\begin{abstract}
Agora todas as narrativas ou sistemas que já nos permitiram julgar que poderíamos definir, de forma não problemática e universal, a concordância pública foram questionados pela aceitação das diferenças - na teoria e na prática artística. Em sua formulação mais extrema, o resultado é o de que o consenso se transforma em ilusão de consenso, seja ele definido em termos de cultura de minoria (erudita, sensível, elitista) ou da cultura de massa (comercial, popular, tradicional), pois ambas são manifestações da sociedade do capitalismo recente, burguesa, informacional e pós-industrial, uma sociedade em que a realidade social é estruturada por discursos (no plural) - é isso que o pós-modernismo procura ensinar (HUTCHEON, 1991, p. 24).
\end{abstract}

“De Cabinda ao Cunene, um só Povo, uma só Nação!” era o slogan do MPLA e da Revolução Angolana. Sufocar as outras línguas, as etnias, os costumes para construir o Estado nacional. Extinguir as diferenças, como vemos, por exemplo, no Mayombe (1979) de Pepetela, em que os guerrilheiros discutem a necessidade da unidade e o tribalismo - ou seja a adoção de costumes e valores que não sejam os do "consenso", definido pelo MPLA, são considerados como traição à causa da independência. Agualusa, por outro lado, põe em xeque, questiona essa ideologia dominante, esse “consenso" à força que foi construído no país, para mostrar realmente o que é: uma ilusão. Não haveria unidade nem mesmo dentro do socialismo pregado nos primeiros anos, pois, como se diz no texto, parafraseando o Hamlet, de Shakespeare: "Entre Marx e Lênin cabem mais profetas do que seria sensato alguém supor” (AGUALUSA, 2010, p. 171).

Outra característica do texto pós-moderno é o hibridismo dos gêneros literários. Há, por exemplo, a apresentação de um poema de Lídia do Carmo Ferreira (AGUALUSA, 2010, p. 19) e há, em várias partes do romance, a apresentação de uma entrevista desta personagem, concedida ao narradorjornalista (AGUALUSA, 2010, p. 42-43). Afinal, "as fronteiras entre os gêneros literários tornaram-se fluidas [...] Entretanto, as fronteiras mais radicais que já se ultrapassaram foram aquelas existentes entre a ficção e a não ficção e - por extensão - entre a arte e a vida" (HUTCHEON, 1991, p. 26-27). Em Estação das chuvas, o que é fato e o que é ficção? - voltamos novamente a esta pergunta. 


\subsection{Os principais eventos históricos narrados}

O romance narra um período bastante longo da história de Angola, desde a época colonial, passando pela independência, até os momentos posteriores. $\mathrm{O}$ autor "[...] se apropria de inúmeros registros discursivos para dar conta de uma História que se faz ao longo de quase 70 anos de lutas, ideais e desejos perdidos pelos caminhos" (SILVA, 2013, p. 115). De uma maneira geral, podemos elencar os fatos históricos principais abordados pelo livro, que são:

a) Emergência do chamado Protonacionalismo, o momento histórico em que os colonos começam a falar da "angolanidade", a pedir reformas e mesmo a ter algum tipo de pensamento independentista. Neste momento, no livro, são retomados inclusive alguns personagens do primeiro romance de Agualusa, $A$ conjura (2009), como é o caso de César Augusto e Jacinto do Carmo Ferreira, respectivamente, avô e bisavô de Lídia do Carmo Ferreira.

Interessante é também a retomada de um episódio do romance citado, mas com mais detalhes na segunda narrativa e até com a mudança da perspectiva de foco narrativo, já que na primeira, em A conjura, o ponto de vista é apenas o do personagem César Augusto, o desertor que chega à casa habitada só por mulheres:

César Augusto desertou nessa mesma noite [...]

E foram entrando e admirando-se porque na casa só havia mulheres, e as mais velhas eram pretas retintas, e as maduras morenas, e as de 30 anos cabritas, e as donzelas eram loiras, tão loiras que dava angústia ver (AGUALUSA, 2009, p. 161).

Transcrevemos, a seguir, um pequeno trecho do episódio, conforme descrito em Estação das chuvas, para comparação, e aqui observamos que o narrador se detém no ponto de vista das mulheres da casa, que recebem os forasteiros:

Em agosto de 1907, chegaram a Chela três homens exaustos e esfarrapados. Eram desertores da coluna portuguesa que tinha ido vingar o vergonhoso desastre militar do Vau de Pembe [...] Os dois soldados partiram ao fim de uma semana, mas César Augusto não os quis seguir: estava apaixonado pelas três bisnetas do madeiriense. Elas tratavam-se por primas, mas a verdade é que, com exceção das duas negras, todas as mulheres naquela casa eram primas entre si e também 
irmãs. Sobre as mais novas, coitadas, pesava a desgraça de serem, ao mesmo tempo, filhas, netas e bisnetas do velho Barbosa (AGUALUSA, 2010, p. 21-22).

b) As discussões sobre a edição do Caderno de poesia negra de expressão portuguesa, coletânea publicada por Mario Pinto de Andrade e Francisco Tenreiro, quando Lídia e Mario discutem. O intelectual angolano quer editar "a primeira manifestação coletiva da negritude em língua portuguesa" (AGUALUSA, 2010, p. 61). Lídia não se sente integrada no movimento negritudista e propõe ironicamente que ele mude o título, publicando um Caderno de poetas negros:

\begin{abstract}
"No fundo", disse, "a verdade é que eu não me identifico com a negritude. Compreendo a negritude, estou solidária com os negros do mundo inteiro e gosto muito dos poemas de Senghor e dos contos de Diop, mas sinto que o nosso universo é outro. Tu, como eu ou o Viriato da Cruz, todos nós pertencemos a uma outra África; àquela mesma África que habita também nas Antilhas, no Brasil, em Cabo Verde ou em São Tomé, uma mistura da África profunda e da velha Europa colonial. Pretender o contrário é uma fraude" (AGUALUSA, 2010, p. $61)$.
\end{abstract}

Agualusa, através de sua protagonista, deixa ver que há necessidade de buscar o Encontro, buscar aliados, a coalizão. Lídia parece manifestar sua consciência de que os problemas enfrentados pelos colonizados, ou excolonizados, eram bastante semelhantes em todo o mundo e somente uma espécie de aliança entre todos poderia representar algum tipo de efetiva mudança. Muito mais do que a união somente através da perspectiva racial, como se pretendia com a negritude. A perspectiva de Lídia é, portanto, pan-africanista, sem dúvida, mas também é internacionalista no seu teor e mais abrangente do que a de Mario Pinto de Andrade.

c) O exílio de Viriato da Cruz na China, devido a sua oposição à liderança do MPLA por Agostinho Neto. No livro lemos que, em 1961, Viriato Cruz teria sido o inspirador para a criação do MPLA, e Mario Pinto de Andrade foi eleito o seu primeiro secretário-geral (AGUALUSA, 2010, p. 81). Logo a seguir, Lídia explica em entrevista ao narrador-jornalista que Viriato combatia o futuro presidente de Angola:

Nessa altura ninguém contestava ainda a liderança de Agostinho Neto? 
- Ninguém! Exceto, é claro, o Viriato da Cruz. O Viriato não aceitou a decisão da conferência nacional. Ficou louco de fúria: "Esse homem é um autocrata!", gritou em plena reunião, o dedo apontado na direção do Neto. Estava completamente sozinho. Mario de Andrade e todos os nossos companheiros de Conakry ficaram em silêncio (AGUALUSA, 2010, p. 87).

Viriato, que teria para o autor do romance a postura do verdadeiro revolucionário, o qual deve ser recordado como realmente grande herói que tinha sido em vida, antevia já naquela época, segundo o romance, a postura ditatorial de Agostinho Neto. Viriato e Lídia eram amigos. Se pensarmos que Lídia pode ser entendida como a metonímia da própria República Popular de Angola, que terminou em 1992, assim como esta foi a data do desaparecimento da personagem (sua morte?), e que ela, Lídia, flertava um pouco com Viriato, talvez possamos pensar que a mensagem do texto é a de que a República Popular de Angola, para ser efetivamente popular, socialista ou livre, precisava "flertar" com o posicionamento político e revolucionário de Viriato Cruz.

Logo a seguir, no livro, temos a notícia de que esse personagem histórico já estava morto:

As últimas cartas que recebera dele, datadas de Pequim, tinham-na deixado inquieta. Nelas, Viriato já não escondia o desapontamento em relação à China: "Socialismo?", perguntava. "Também será isto o socialismo? Basta-me franquear os quinhentos metros que separam as ruas asfaltadas dos bairros mais pobres para ser assaltado pela repentina sensação de haver recuado vários séculos na História” [...] Foi aí, em 1973, poucos meses antes da revolução de Abril, que Viriato morreu. Os médicos diagnosticaram um enfarte de miocárdio (AGUALUSA, 2010, p. 138-139).

d) A proclamação da Independência é o acontecimento que abre a narrativa, até mesmo com a reprodução de um pequeno trecho do discurso lido por Agostinho Neto, em Luanda, no 11 de novembro de 1975.

e) A Revolta Activa foi o nome atribuído ao grupo que se manteve fiel a Mario Pinto de Andrade, quando o MPLA se dividiu em três grupos: o de Mario; a Revolta do Leste, liderada por Daniel Chipenda; e a "Ala presidencial", fiel a Agostinho Neto. Lídia participou do grupo de Mario de Andrade.

f) A tentativa de golpe de Nito Alves: o fraccionismo. "Na madrugada do dia 27 de maio de 1977 ouvi o estrépito dos tiros mas não acordei” (AGUALUSA, 
2010, p. 171). Nito Alves, Ministro do Interior de Angola desde a Independência, foi expulso do MPLA em 21 de maio de 1977. Reagiu, invadindo a prisão de Luanda e libertando outros apoiadores. A reação do governo foi duríssima, exterminando não só os integrantes do movimento, mas também seus familiares e conhecidos. "Com a gente de Nito Alves não houve piedade. Morreram aos milhares" (AGUALUSA, 2010, p. 181).

Outros acontecimentos também são referidos, como a batalha de Quifangondo, quando a coluna invasora, formada pela FNLA (Frente Nacional de Libertação de Angola) com apoio de exércitos zairenses e da África do Sul, chegou até Cacuaco (município que separa Luanda do Bengo) e enfrentou a resistência das FAPLA (Forças Armadas Populares de Libertação de Angola), que era o braço armado do MPLA, com o apoio das Forças Armadas de Cuba, em Quifangondo. $O$ resultado poderia ter sido desastroso se os invasores entrassem em Luanda e impedissem a proclamação da Independência. Aqui, surge o personagem Ángel Martínez, mercenário cubano que luta a favor dos invasores. Preso, resolve denunciar todas as mazelas do capitalismo, fazendo o jogo das autoridades angolanas para se manter vivo.

\subsection{A presença fantasmática do autor}

A narrativa cuida nos primeiros capítulos da estória de Lídia do Carmo Ferreira, sendo prioritariamente narrada em primeira pessoa por um narrador que se apresenta na parte 6, intitulada "O dia eterno", e assume o romance, tomando-o de assalto e passando a contar, protagonisticamente, a sua própria estória. É o narrador-jornalista, que em nenhum momento revela-nos o seu próprio nome:

Enquanto o presidente discursava no largo Primeiro de Maio, Zorro avançava para Paulete através da multidão, a abraçava, e depois cumprimentou Borja Neves. Enquanto Lídia pensava na morte, fechada no seu quarto, Ángel Martínez enterrava um morto para lhe tomar o nome. Enquanto tudo isto acontecia, preparava-me para fugir do Huambo (AGUALUSA, 2010, p. 114). 
Este narrador-jornalista possui traços que nos permitem identificá-lo com o autor José Eduardo Agualusa. Como o autor, ele também nasceu no Huambo, em 1960. É jornalista. Essas similaridades entre os dois, personagem e autor, remetem-nos àquilo que Lejeune chamou de "presença fantasmática” do autor no texto:

\footnotetext{
Qual seria essa verdade da qual o romance permite chegar mais perto, senão a verdade pessoal, individual, íntima, do autor, isto é, aquilo que todo projeto autobiográfico visa? Por assim dizer, é enquanto autobiografia que se decretou ser o romance mais verdadeiro.

O leitor é assim convidado a ler os romances não apenas como ficções remetendo a uma verdade da "natureza humana", mas também como fantasmas reveladores de um indivíduo. Denominarei essa forma indireta de pacto autobiográfico como pacto fantasmático (LEJEUNE, 2014, p. 50).
}

Assim, segundo Lejeune, embora não possamos dizer que o personagem seja José Eduardo Agualusa, podemos inferir que ele traz elementos e características, bem como talvez alguns episódios memorialistas, do autor empírico do livro.

\subsection{Os limites entre a história e a ficção}

Agualusa põe em xeque a história oficial de Angola, principalmente após a Independência. Questiona, critica, constrange, demonstra o absurdo e nos permite enxergar não a sua versão, mas a possibilidade de novas versões, uma possibilidade de liberdade. Tal é, inclusive, a pretensão da "metaficção historiográfica”, por exemplo.

Um dos episódios mais interessantes a esse respeito é o da criação da televisão pelos presos políticos. Renata Flavia da Silva nos diz que:

a televisão inventada pelo jovem Zorro é a representação do desejo de produzir um efeito de real mais do que verossimilhança. Os presos da cadeia de São Paulo assistiam à criação de uma nova história, com base no real, mas fictícia e, por isso, livre para dizer quase tudo (SILVA, 2013, p. 118). 
Como em 1984, o romance distópico de George Orwell (2009) em que o protagonista Smith, operário do Ministério da Verdade, no seu cargo público, vai reescrevendo as notícias de acordo com as ordens que recebe de seus superiores, em Estação das chuvas o processo é semelhante, porque os presos acreditam nas notícias proferidas, através da caixa de madeira:

\begin{abstract}
Fui nomeado diretor dos serviços informativos da "televisão". Era divertido: ao princípio ainda tentamos reproduzir a realidade, ou aquilo que supúnhamos que seria a realidade. Construímos o telejornal com base em informações trazidas pelos guardas, pelos familiares e amigos que nos visitavam, ou retiradas dos raros jornais e revistas que conseguíamos obter. Pouco a pouco começamos a inventar breves notícias, e logo outras de maior impacto, enredando os restantes presos num universo de ficção (AGUALUSA, 2010, p. 190).
\end{abstract}

A televisão é a subversão da realidade; é um momento de "ultrapassagem das fronteiras entre o factum e o fictum" (SILVA, 2013, p. 115). É alegoria da própria Angola, em que uma narrativa oficial foi imposta sem a possibilidade de qualquer oposição. É como se Agualusa nos apresentasse a subversão do mito da caverna de Platão. Em vez de sairmos para as luzes do sol, pois não sabemos nem se essa luz é real, devemos nos aprofundar na caverna, ir mais fundo ainda para descobrirmos e aprendermos que a caverna é realmente falsa, como são falsas as nossas crenças e o quanto são pesados os imensos grilhões que apertam nossos braços, pernas e pescoços.

$\mathrm{Na}$ realidade fantasiosa criada pelos presos políticos na cadeia de São Paulo, algumas notícias não eram aceitas e, por isso, deviam ser desmentidas no noticiário seguinte, o que, em nossa opinião, indica a tentativa de construção de uma via mais democrática e consensual desta pseudorrealidade. $\mathrm{O}$ universo ficcional criado pelos presos devia satisfazer a todos. Era o estabelecimento de um novo consenso. E ainda parece que o autor nos diz que, já que no cativeiro estavam misturados todos os inimigos do MPLA, e inimigos entre si, esse episódio dos presos buscando uma realidade que fosse aceita por todos indica também que sempre houve a possibilidade do entendimento, do encontro entre todos aqueles grupos políticos adversários que pegaram em armas para brigar por seus posicionamentos, ideias e opiniões. Se o entendimento era possível, a discórdia interessava então a quem? 


\subsection{A realização da poética do encontro}

Em Estação das chuvas é realizado o encontro dos adversários que são obrigados a conviver amistosamente na cadeia de São Paulo. É o encontro das etnias, das ideologias diferentes, dos inimigos políticos. Na cela, personagens que são ou foram opositores, antagonistas, passam a ter o convívio uns com os outros e acabam chegando ao entendimento. Ali, naquela cela, que é uma espécie de microcosmo de toda prisão, e de toda Angola, estão o narrador-jornalista, Zorro, Joãoquinzinho, Borja Neves, o mercenário cubano Ángel Martínez, Santiago e o Coronel Aristides Lobo d'África. Estão ali todos, ou quase todos, os matizes ideológicos que estiveram envolvidos em alguma disputa no território angolano. Se no espaço confinado podiam conviver, por que não o poderiam no espaço livre de Angola, sem pegar em armas para matar uns aos outros? Eram obrigados a se respeitar dentro da cela. Só quem não estava ali dentro e confinado era o MPLA. Será que o autor está nos dizendo que o MPLA tinha se tornado o principal problema para o país de Luanda?

Sobre esse novo consenso estabelecido a partir da participação de mais agentes sociais, é possível afirmar que:

\footnotetext{
É na emergência dos interstícios - a sobreposição e o deslocamento dos domínios da diferença - que as experiências intersubjetivas e coletivas de nação [nationness], o interesse comunitário ou o valor cultural são negociados. De que forma se formam sujeitos nos "entre-lugares", nos excedentes da soma "partes" da diferença (igualmente expressas como raça/classe/gênero etc.)? De que modo chegam a ser formuladas estratégias de representação ou aquisição de poder [empowerment] no interior das pretensões concorrentes de comunidades em que, apesar de histórias comuns de privação e discriminação, o intercâmbio de valores, significados e prioridades pode nem sempre ser colaborativo e dialógico, podendo ser profundamente antagônico, conflituoso e até incomensurável? (BHABHA, 2019, p. 20).
}

Homi K. Bhabha irá nos falar sobre a incidência de embates culturais, principalmente após a descolonização. Nesses embates, buscar-se-á a recuperação de um passado: reencenar o passado para compreender o presente. Entretanto, somente quem tem o poder de narrar tem a chance de construir o espaço/tempo a seu favor, sugerir ou impor a sua versão. Este processo pode se 


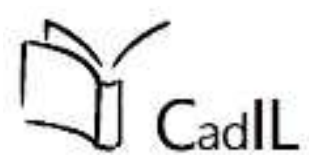

dar de uma forma conflituosa ou consensual. Agualusa demonstra que talvez ele pudesse ter se dado de forma consensual em Angola.

Inocência Mata contribui para essa discussão, estabelecendo que o processo de unificação em Angola poderia ter se dado buscando, ao invés da nação, a cidadania:

[...] que a nação não tem de - nem pode, historicamente - ser a síntese orgânica, mas uma entidade com fissuras e tensões em que a homogeneidade idealizada teria que ser submersa numa realidade feita de impasses e descompassos; e que, em vez da nacionalidade, a instância do país moderno deveria ser cidadania (MATA, 2010, p. 92).

É sobre cidadania que talvez Agualusa nos fale quando nos apresenta o encontro das diferenças, mas com entendimento. Ou no episódio da televisão, quando o consenso decide quais são as notícias aceitas pelo grupo e as que não o são. No processo de construção da cidadania, todos os indivíduos são importantes, pois todos são cidadãos, com personalidade jurídica, com capacidade para exercer direitos e contrair obrigações. Ao contrário de outros processos, como nos indica, por exemplo, Hannah Arendt em As origens do totalitarismo (2018), em que se procura a homogeneização e a atomização de todos os indivíduos numa aglomeração social, com o fim da construção de um regime totalitário. A perspectiva do totalitarismo talvez seja mais semelhante ao que o MPLA quis construir em Angola.

E esse ir ao encontro tem também o sentido de ir além, além do que reconhecemos, além de nossas tradições, como nos diz, ainda, Bhabha:

\footnotetext{
"Além" significa distância espacial, marca um progresso, promete um futuro; no entanto, nossas sugestões para ultrapassar a barreira ou o limite - o próprio ato de ir além - são incogniscíveis, irrepresentáveis, sem um retorno ao "presente", que, no processo de repetição, torna-se desconexo e deslocado. O imaginário da distância espacial - viver de algum modo além da fronteira de nossos tempos - dá relevo a diferenças sociais, temporais, que interrompem nossa noção conspiratória da contemporaneidade cultural (BHABHA, 2019, p. 24).
}

Esse encontro se traduz na possibilidade de construção de outra Angola que não é realmente aquela preconizada pelo MPLA, mas uma para além do que imaginamos, mas sempre se fez (e se faz) necessária. Não com os iguais, mas 
respeitando as diferenças, entre os diferentes. Porque somos todos diferentes uns dos outros.

\section{Conclusão}

É possível identificarmos no texto pelo menos três momentos em que há um chamamento ou efetivamente a realização de um encontro entre os diversos personagens que compõem o romance como em uma perspectiva para a possibilidade de construção de outra Angola.

Primeiro, quando Lídia, demonstrando uma consciência para além do seu tempo (AGUALUSA, 2010, p. 61), se recusa a participar da coletânea de poetas negros de Mario Pinto de Andrade e insta o amigo sobre os limites da negritude. Seria preciso ir além da negritude e buscar uma aliança com os povos colonizados do mundo inteiro, que sofriam e sentiam, ou sentiram, o peso e o jugo da colonização. Aqui, há o chamamento para um encontro amplo em que se pudessem discutir alternativas para os problemas que todos enfrentavam ou enfrentaram. Se fizéssemos a leitura do posicionamento de Lídia a partir de Yves Benot, por exemplo, através do seu Ideologias das independências africanas (1981), poderíamos arriscar que a perspectiva dela era mais próxima da que era defendida pelas colônias inglesas africanas, lideradas por Nkrumah, de Gana, o qual, no Congresso de Manchester (1945), propôs o "Apelo aos povos colonizados", direcionado a todos os povos do terceiro mundo, e Mario Pinto de Andrade estava mais próximo da posição das colônias francesas, com Senghor e Cesaire, por exemplo.

O segundo momento é quando os adversários são reunidos na cela, na cadeia de São Paulo. O colonizador português, o mercenário cubano, os extremistas de esquerda, os líderes populares, combatentes, etc., enfim, todos são obrigados a conviver lado a lado, dia a dia, e suas diferenças não são maiores do que suas similaridades. Aqueles homens convivem entre si e conseguem organizar a vida diária na prisão, inclusive com a realização de cursos, nos quais cada um se aplicava no que era melhor. O narrador-jornalista, por exemplo, lecionava literatura angolana, enquanto outros davam aulas de primeiros 
socorros, quicongo ou astronomia, entre diversos outros assuntos que os presos ensinavam uns para os outros. Lídia, que também estava presa, fazia chegar até eles algumas monografias que escrevia especialmente para os estudos.

O terceiro momento é quando os presos organizam a televisão (AGUALUSA, 2010, p. 190). Com a televisão, há a negociação da realidade, principalmente no telejornal, em que algumas notícias que não eram aceitas deviam ser corrigidas na edição seguinte. Estava havendo o consensualismo entre todos aqueles homens tão diversos, de vários matizes ideológicos, políticos e étnicos. Essa realidade negociada, em nosso entendimento, era a criação do novo, de uma Angola possível, para além do campo de batalha e do derramamento do sangue.

Há ainda duas cenas no romance que são ricas no simbolismo, no significado e na demonstração do encontro e desencontro, construção e destruição. Ambas as cenas envolvem o personagem Santiago. Na primeira, Santiago está cego, em razão dos castigos e torturas sofridos, e recebe a visita de uma autoridade que imediatamente identificamos que só poderia ser o próprio Agostinho Neto: “- Sabes quem eu sou? Santiago sabia. Não podia ver, mas era como se o visse" (AGUALUSA, 2010, p. 184). O autor nos mostra que, na sua concepção, o presidente sabia de todos os crimes que eram cometidos em seu nome, ao contrário do que alguns pensavam. Nada era feito sem o seu conhecimento. Ele sabia das mortes, torturas, prisões e maus tratos:

Bateram-lhe até que desmaiou, depois puseram-lhe a cabeça dentro de um balde cheio de água suja e quando abriu os olhos voltaram-lhe a bater. Por fim alguém lhe mostrou uma navalha. $\mathrm{O}$ mundo ficou escuro, um lugar sem luz e sem tempo. Podem ter passado dias, ou apenas algumas horas. Santiago não é capaz de precisar (AGUALUSA, 2010, p. 183-184).

Agostinho Neto e o MPLA, na visão do autor, são os maiores representantes de todas as coisas negativas que aconteceram em Angola. No texto, são os representantes do desencontro, da destruição.

A segunda passagem que fazemos notar dá-se quando o narradorjornalista encontra Santiago na rua e o chama, bem no final do livro, alguns anos após estarem livres da prisão: 
Era ele, uns óculos espelhados presos à cabeça com fita adesiva. Conduzia a mota. Sentado atrás estava um velho sem braços, a barba branca em desalinho, olhos vermelhos e brilhantes como brasas. Santiago voltou a cabeça de monstro na minha direção [...]

Saltou da mota e abraçou-me. Bateu-me com força nas costas. Por fim desprendeu-se e apontando o velho, apresentou-o:

- Este é Antonine Ninganessa! (AGUALUSA, 2010, p. 214).

Cena surpreendente e absurda a que assistimos lendo estas páginas: um cego, Santiago, pilotando uma moto e trazendo na garupa o profeta Antonine Ninganessa, que foi quem assassinou seu pai:

Porém, Ninganessa olhou para ele desvairado e gritou-lhe que tu continuas branco, um raio de um branco, pois só um branco seria capaz de pensar uma coisa dessas. Ordenou de seguida a dois homens que o agarrassem. Vendo-o bem seguro, pegou numa catana e cortou-lhe a cabeça com um único golpe (AGUALUSA, 2010, p. 73).

No universo construído por Agualusa, o universo do encontro, da reconciliação, era possível que houvesse o encontro e a reconciliação de Santiago com Ninganessa, um personagem que simbolizava o desvario, o fanatismo, uma espécie de liderança popular fanática, enfim alguém deveras hediondo. Ainda assim, até com ele era possível a reconciliação, mas provavelmente esta não era possível com Agostinho Neto ou o MPLA. 


\section{Referências}

AGUALUSA, José Eduardo. A conjura. Rio de Janeiro: Gryphus, 2009.

AGUALUSA, José Eduardo. Estação das chuvas. Rio de Janeiro: Língua Geral, 2010.

APPIAH, Kwane Anthony. Na casa de meu pai. Tradução de Vera Ribeiro. Rio de Janeiro: Contraponto, 1997.

ARENDT, Hannah. Origens do totalitarismo. São Paulo: Companhia das Letras, 2018.

BENOT, Yves. Ideologias das independências africanas. Tradução de Carlos da Veiga Ferreira. Lisboa: Sá da Costa Editora, 1981. v. 1.

BHABHA, Homi K. O local da cultura. 2. ed. Tradução de Myriam Ávila et al. Belo Horizonte: Editora UFMG, 2019.

HUTCHEON, Linda. Poética do modernismo. Tradução de Ricardo Cruz. Rio de Janeiro: Imago Ed., 1991.

LEITE, Ana Mafalda. Oralidades e escritas pós-coloniais. Estudos sobre literaturas africanas. Rio de Janeiro: EdUERJ, 2012.

LEJEUNE, Philippe. O pacto autobiográfico. De Rousseau à Internet. 2. ed. Organização de Jovita Maria Gerheim Noronha, tradução de Jovita Maria Gerheim Noronha e Maria Inês Coimbra Guedes. Belo Horizonte: Editora UFMG, 2014.

MATA, Inocência. Ficção e história na Literatura Angolana. O caso de Pepetela. Lisboa: Edições Colibri, 2010.

NETO, António Agostinho. Aqui no cárcere, 2010. Fundação Agostinho Neto. Disponível em:

<http://www.agostinhoneto.org/index.phpoption=com_content\&view=article\& $\mathrm{id}=567: 0$-choro-de-africa\&catid=45: sagrada-esperanca\&Itemid $=233>$. Acesso em: 1 nov. 2019.

ORWELL, George. 1984. Tradução de Heitor de Aquino Ferreira. Rio de Janeiro: Companhia das Letras, 2009.

SILVA, Renata Flavia da. Estação das chuvas: história e literatura na encruzilhada do romance. Mulemba - Revista Científica da UFRJ, Rio de Janeiro, v. 5, n. 8, p. 114-124, jan./jul. 2014. Disponível em: <https://revistas.ufrj.br/index.php/mulemba/article/view/4969>. Acesso em: 1 nov. 2019.

Artigo recebido em 16 de março de 2020 e aceito em 4 de maio de 2020. 